\title{
Fungsi Tiroid Pasca Radioterapi Tumor Ganas Kepala- Leher
}

\author{
Ade Chandra, Sukri Rahman
}

\begin{abstract}
Abstrak
Latar Belakang : Radioterapi merupakan salah satu pilihan modalitas pada penatalaksanaan tumor ganas kepala dan leher selain pembedahan dan kemoterapi. Radioterapi pada tumor ganas kepala dan leher dapat mempengaruhi kelenjar tiroid dan merangsang kelainan. Diantara efek samping akibat radioterapi pada kelenjar tiroid tersebut, hipotiroid merupakan kelainan yang paling sering ditemukan. Hipotiroid akibat radioterapi ini bersifat irreversibel dan mempengaruhi kualitas hidup pasien. Tujuan : Untuk mengetahui fungsi tiroid setelah dilakukan radioterapi pada pasien tumor ganas kepala dan leher. Tinjauan Pustaka : Hipotiroid merupakan efek samping yang paling sering ditemukan pasca radioterapi tumor ganas kepala dan leher. Kelainan pada tiroid pasca radioterapi dihubungkan dengan kerusakan sel dan pembuluh darah kecil kelenjar tiroid serta fibrosis kapsul kelenjar tiroid yang selanjutnya menyebabkan kelenjar tiroid mengecil. Kesimpulan : Radioterapi pada pasien tumor ganas kepala dan leher dapat menimbulkan efek samping berupa hipotiroid yang dibuktikan dengan peningkatan nilai TSH dan penurunan nilai T4 pada pemeriksaan fungsi tiroid.
\end{abstract}

Kata kunci: Radioterapi, tumor ganas kepala dan leher, hipotiroid

\begin{abstract}
Background: Radiotherapy is one option of modality in the management of head and neck cancer beside surgery and chemotherapy. Radiotherapy in the head and neck cancer can affect the thyroid gland and stimulates the gland disorders. Among the side-effects of radiotherapy on the thyroid gland, hypothyroidism is a disorder most commonly found. Hypothyroidism due to radiotherapy is irreversible and affect quality of life of patients Objective: To determine the function of the thyroid after radiotherapy in patients with the head and neck cancer. Literature Review: Hypothyroidism is the most common side effects found after radiotherapy of the head and neck cancer. Abnormalities of the thyroid after radiotherapy is associated with damage cells and small blood vessels of the thyroid gland and capsule fibrosis of the thyroid gland which in turn causes the thyroid gland to shrink. Conclusion: Radiotherapy in patients with the head and neck cancer can cause side effects such as hypothyroidism as evidenced by the increase in the value of TSH and T4 in the impairment of thyroid function tests.
\end{abstract}

Keywords: Radiotherapy, head and neck cancer, hypothyroid

Affiliasi penulis :, Ade Chandra, Sukri Rahman, Fakultas Kedokteran Universitas Andalas Padang.

Korespondensi : Ade Chandra, Bagian THT-KL Fakultas Kedokteran Universitas Andalas

\section{Pendahuluan}

Tumor ganas sel skuamosa kepala dan leher adalah keganasan yang berasal dari epitel traktus aerodigestif atas yang meliputi sinus paranasal, kavum nasi, rongga mulut, faring dan laring. ${ }^{1}$ Tumor ganas kepala dan leher merupakan tumor ganas urutan ke enam dari seluruh tumor ganas dan urutan ke delapan yang menyebabkan kematian diseluruh dunia dan insidennya sangat bervariasi di berbagai Negara., Kejadian tumor ganas kepala dan leher di Amerika Utara dan Eropa diperkirakan 3-4\% dari seluruh tumor ganas, sedangkan di Asia Tenggara dan negara Afrika diperkirakan $8-10 \%$ dari seluruh tumor ganas. Tumor ganas kepala dan leher lebih lebih sering terjadi pada pria. ${ }^{1}$

Tumor ganas sel skuamosa kepala dan leher merupakan tumor ganas yang etiologinya dihubungkan dengan rokok dan alkohol. ${ }^{1}$ Akhir-akhir ini kejadiannya dihubungkan dengan Human Papillomavirus (HPV). ${ }^{1,3}$
Pemilihan modalitas pengobatan pada tumor ganas kepala dan leher didasarkan pada ukuran, lokasi tumor primer, keterlibatan kelenjar getah bening (KGB) dan kondisi umum pasien. ${ }^{4}$ Radioterapi merupakan salah satu pilihan modalitas pada penatalaksanaan tumor ganas selain pembedahan dan kemoterapi. ${ }^{1}$

Radioterapi pada tumor ganas kepala dan leher dapat mempengaruhi kelenjar tiroid dan merangsang kelainan kelenjar tersebut. ${ }^{5}$ Diantara efek samping tersebut, hipotiroid merupakan kelainan yang paling sering ditemukan pada pasien pasca radioterapi di leher. ${ }^{5,6}$

\section{Anatomi}

Kelenjar tiroid adalah suatu organ yang berbentuk kupu-kupu, terletak di depan trakea tepatnya pada cincin trakea kedua dan ketiga. ${ }^{7}$ Terdiri dari dua lobus yang dihubungkan oleh ismus pada garis tengah. ${ }^{7,8}$ Kelenjar tiroid meluas dari vertebrae servikal tujuh sampai vertebrae torakal satu. ${ }^{8}$ Setiap lobus memiliki panjang $3-4 \mathrm{~cm}$, lebar $2 \mathrm{~cm}$ dan berat 30 gram. $^{7,8}$

Kelenjar tiroid dikelilingi oleh fasia pretrakea yang disebut juga sebagai pelindung peritiroid. Pada 
bagian posterior, fasia ini menebal, melekatkan kelenjar tiroid ke kartilago krikoid. Fasia ini merupakan ligamentum lateral tiroid (ligamentum Berry). ${ }^{8}$

Permukaan anterior kelenjar tiroid berhubungan dengan permukaan dalam otot sternotiroid, otot sternohioid dan otot omohioid. Pada bagian lateral, kelenjar tiroid berhubungan dengan selubung karotis (arteri karotis interna, vena jugularis interna, nervus vagus). Pada bagian posterior, lobus tiroid bagian superior berhubungan dengan laring dan laringofaring sedangkan bagian medial kelenjar tiroid berhubungan dengan trakea dan esofagus. ${ }^{8}$

Kelenjar tiroid mendapatkan suplai darah dari arteri tiroid superior yang merupakan cabang arteri karotis eksterna dan arteri tiroid inferior yang berasal trunkus tiroservikal atau arkus aorta. ${ }^{7}$ Aliran vena tiroid terdiri dari tiga yaitu superior, media dan inferior. Vena tiroid superior akan mengalir ke vena jugularis superior, vena tiroid media akan mengalir langsung ke vena jugularis interna sedangkan vena tiroid inferior mengalir ke vena jugularis interna atau vena brakiosefalika. $^{8}$ KGB tiroid terutama mengalir ke central compartment, tetapi beberapa juga mengalir KGB paratrakea. ${ }^{7}$

\section{Histologi}

Secara histologi, struktur utama kelenjar tiroid adalah folikel tiroid yang terdiri dari satu lapisan sel folikel tiroid yang dikelilingi oleh membran basalis. Folikel berisi materi koloid yang mengandung tiroglobulin, prekusor makromolekul dan merupakan tempat penyimpanan protein untuk hormon tiroid: tiroksin $\left(T_{4}\right)$ dan triiodotironin $\left(T_{3}\right)^{7,9}$ Ukuran folikel ini bervariasi meskipun dalam satu kelenjar tiroid, tetapi biasanya berukuran $200 \mu \mathrm{m}$. Setiap $20-40$ folikel dipisahkan jaringan ikat pendukung yang merupakan grup sel C (dikenal juga sebagai sel parafolikuler) yang akan memproduksi kalsitonin., 70

\section{Fisiologi}

Fungsi utama kelenjar tiroid adalah untuk menyediakan hormon tiroid yang memadai untuk regulasi fungsi tubuh, antara lain pengeluaran energi dan metabolisme. Hormon tiroid adalah iodinated hormone, oleh karena itu dibutuhkan kemampuan kelenjar tiroid untuk mengkonsentrasikan iodium dari sirkulasi dan mengatur iodium untuk bergabung ke dalam molekul hormon tiroid. ${ }^{7}$

Ciri yang paling penting dari sel tiroid adalah kemampuan untuk mengambil iodium dari sirkulasi. ${ }^{7}$ Proses ini diselesaikan oleh natrium-iodide symporter (NIS) yang terletak di basal membran tirosit. Proses ini dilakukan secara aktif yang membutuhkan energi untuk mengkonsentrasikan iodium dalam tirosit 20 - 40 kali di atas level sirkulasi dan diselesaikan oleh transpor natrium ke dalam sel. $^{7,11}$

Untuk pengaturan iodium, enzim thyroid peroxidase (TPO) bersama dengan hidrogen peroksida dibutuhkan untuk pembentukan iodium inorganik dan menggabungkannya ke dalam residu tirosin dari tiroglobulon. ${ }^{7,11}$ Selanjutnya terjadi produksi monoiodotirosin (MIT) dan diiodotirosin yang kemudian masing-masing MIT dan DIT membentuk $\mathrm{T}_{3}$ atau dua DIT membentuk $\mathrm{T}_{4} \cdot{ }^{11}$ Proses ini terjadi pada bagian apikal membran sel tiroid yang berhadapan dengan koloid. ${ }^{7,11}$ Sekali hormon tiroid disintesis, hormon ini akan disimpan dalam bentuk ikatan dengan molekul tiroglobulin pada koloid yang terletak di folikel tiroid. Produksi hormon tiroid berada dibawah kontrol kelenjar pituitari yang mensekresi Thyroid Stimulating Hormone (TSH). Sekresi TSH juga dikontrol oleh Thyroid Releasing Hormone (TRH) yang berasal dari hipotalamus. ${ }^{9}$ Dibawah stimulasi tirotropin (TSH), kelenjar tiroid menerima sinyal bahwa tubuh membutuhkan hormon tiroid dan fragmen tiroglobulin masuk ke tirosit (pinositosis) dan dipecah oleh endopeptidase di dalam endosom dan lisosom. Dari proses ini, dihasilkan tiroksin $\left(T_{4}\right)$ dan triiodotironin $\left(T_{3}\right)$ serta dilepaskan ke sirkulasi. Pada keadaan normal, produksi hormon tiroid terutama berupa $\mathrm{T}_{4} \quad(90 \%$ atau $75-100 \mu \mathrm{g} / \mathrm{d})$ dan sedikit $\mathrm{T}_{3}(10 \%$ atau $6 \mu \mathrm{g} / \mathrm{d}){ }^{7}$

\section{Pemeriksaan Fungsi Kelenjar Tiroid}

Pemeriksaan yang dapat dilakukan untuk menilai fungsi tiroid antara lain ${ }^{9,11}$ TSH, T4 dan T3

TSH digunakan untuk mengukur hormon yang dihasilkan oleh kelenjar pituitari yang akan menstimulasi kelenjar tiroid. $^{9}$ Pemeriksaan ini harus dilakukan jika terdapat kecurigaan adanya hipertiroid atau hipotiroid dan pemeriksaan ini adalah tes yang paling baik untuk skrining abnormalitas dari fungsi tiroid. Nilai normal TSH berbeda diantara laboratorium, tetapi nilai umum digunakan pada orang dewasa adalah 0,3 - $4 \mathrm{mIU} / \mathrm{L}$. Pasien didiagnosis dengan hipotiroid jika pada pemeriksaan nilai TSH lebih dari nilai normal. $^{9,11}$

T4 menggambarkan status fungsional kelanjar tiroid. ${ }^{10}$ Kombinasi pemeriksaan $\quad \mathrm{T}_{4}$ dengan TSH akan memberikan konfirmasi diagnosis pada pasien dengan abnormalit fungsi tiroid. Nilai normal $\mathrm{T}_{4}$ adalah antara $65-155 \mathrm{nmol} / \mathrm{L}^{9}$

Pemeriksaan T3 dilakukan jika diagnosis tidak bisa ditegakkan setelah melihat hasil pemeriksaan TSH dan $T_{4}$. Nilai normal $T_{3}$ adalah $1-2,6 \mathrm{nmol} / \mathrm{L}{ }^{9}$ Selain itu, pemeriksaan $\mathrm{T}_{3}$ dapat juga digunakan untuk menentukan beratnya hipertiroid. $^{11}$

\section{Hipotiroid}

Hipotiroid adalah suatu keadaan dimana tiroid tidak mampu menghasilkan hormon tiroid ( $T_{3}$ dan $T_{4}$ ) yang cukup untuk mempertahankan kadar hormon tiroid dalam darah dan untuk memenuhi kebutuhan jaringan perifer. $^{9}$ Gejala hipotiroid bervariasi, tetapi yang sering ditemukan antara lain adalah tidak tahan dingin, kelelahan, konstipasi, jantung terasa berdebar dan penurunan berat badan. 
Pada pemeriksaan fisik dapat ditemukan antara lain kulit kering, bradikardi, peningkatan tekanan darah dan non pitting edema perifer. $^{9,11,12}$

Hipotiroid dapat dibedakan menjadi hipotiroid klinis dan hipotiroid subklinis. ${ }^{9,11}$ Hipotiroid klinis adalah terjadinya peningkatan kadar serum TSH disertai dengan penurunan kadar serum $\mathrm{T}_{4}$. Sedangkan hipotiroid subklinis adalah suatu keadaan dimana kadar serum TSH di atas nilai normal sedangkan kadar $T_{4}$ normal serta pasien tidak memiliki gejala dan tanda hipotiroid. ${ }^{9,11}$

Hipotiroid juga dapat diklasifikasikan menjadi hipotiroid primer dan hipotiroid sekunder. Hipotiroid primer disebabkan oleh penyakit atau pengobatan dapat menyebabkan terjadinya kerusakan sel kelenjar tiroid atau mengganggu biosintesis hormon tiroid. ${ }^{11,12}$ Hipotiroid sekunder disebut juga sebagai hipotiroid sentral atau hipotirotropik. Hipotiroid sekunder ini dapat disebabkan oleh penyakit di hipotalamus atau pituitari dimana terjadi penurunan $\mathrm{TRH}$, yang disertai dengan pengurangan kadar $\mathrm{TSH}^{12}$

\section{Radioterapi pada Tumor Ganas Kepala dan Leher}

Radioterapi adalah suatu modalitas pengobatan tumor ganas yang menggunakan partikel atau gelombang berenergi tinggi seperti sinar $\mathrm{X}, \quad$ gamma, elektron atau proton untuk menghancurkan atau merusak sel. ${ }^{13}$ Radioterapi memainkan peranan penting dalam pengobatan tumor ganas kepala dan leher baik digunakan sebagai modalitas tunggal atau pengobatan adjuvant yang dikombinasikan dengan pembedahan. ${ }^{4,14}$ Radioterapi konvensional pada tumor ganas kepala dan leher biasanya menggunakan satu bidang anterior dan dua bidang lateral. Beberapa tulang penanda digunakan untuk menentukan batas pada rencana radioterapi konvensional. ${ }^{13}$ Terdapat risiko hot spot atau cold spot pada batasan daerah diantara bidang ini. ${ }^{13,14}$ Terdapat dua metode utama yang digunakan untuk menurunkan kemungkinan ini $^{13}$ :

Teknik penyesuaian divergen; Teknik ini didasarkan pada rotasi tempat tidur atau perubahan sudut collimator.Divergen dicegah pada batas bidang lateral dan anterior dengan modifikasi rotasi sudut tempat tidur dan atau sudut collimator sebagai bidang lateral pada lapangan yang direncanakan. Sudut tempat tidur dan atau collimator biasanya bervariasi antara $2^{0}$ sampai $4^{0}$.

Penggunaan collimator asimetris atau half block; Collimator asimetris adalah sebuah komponen linac yang memungkinkan collimator bergerak secara bebas sehingga bidang asimetris dapat dibentuk. Masalah sinar divergen dapat diatasi dengan teknik ini. Disamping itu teknik ini mudah digunakan.
Half block akan menutup sebagian sinar yang berasal dari tengah sehingga sinar tidak mengenai bagian lateral dan terbatas pada bidang supraklavikula anterior.

Secara praktis, dibuat celah $3-5 \mathrm{~mm}$ diantara bidang anterior dan bidang supraklavikula untuk mencegah hot spot dan cold spot. Bagaimanapun, distribusi dosis penyinaran harus diperiksa karena interval celah ini dapat merubah energi foton. ${ }^{13}$

\section{Tumor Ganas Nasofaring}

Radioterapi konvensional pada tumor ganas nasofaring yaitu dengan dua bidang lateral dan satu bidang anterior supraklavikula. ${ }^{13,14}$ Batas bidang lateral (tumor primer dan leher bagian atas); pada bagian superior : dasar tengkorak meliputi sinus sfenoid, inferior : plika vokalis, posterior : prosesus spinosus vertebrae, anterior : $2-3 \mathrm{~cm}$ batas tumor yang meliputi pterigoid plate dan sepertiga posterior sinus maksila. Jika terdapat keterlibatan KGB supraklavikula, maka KGB mediastinum disertakan dengan bidang anterior. Sedangkan batas bidang supraklavikula; superior : batas inferior bidang lateral, inferior : dasar persendian sternoklavikula dan lateral : meliputi duapertiga klavikula. ${ }^{13}$

\section{Dosis radioterapi :}

Bidang berlawanan yang paralel: 2 Gy/hari sampai dosis total 46 Gy. ${ }^{43}$ Radiasi ini menggunakan sinar $\mathrm{X}$ atau Co-60 $6 \mathrm{MeV}$. Dosis leher bagian posterior disempurnakan sampai 50 Gy. $^{13}$ Setelah 50 Gy, sisa 20 Gy diberikan untuk tumor primer ditambah $2 \mathrm{~cm}$ bebas tumor sehingga total dosis primer adalah 70 Gy. ${ }^{4,13-15}$

Dosis leher elektif (No) adalah 50 Gy. ${ }^{13,16}$ Jika terdapat KGB kurang $3 \mathrm{~cm}$ : total dosis KGB 66 Gy atau jika terdapat KGB lebih $6 \mathrm{~cm}$ : total dosis KGB 70 Gy. ${ }^{13}$

\section{Tumor Ganas Orofaring}

Bidang radioterapi konvensional orofaring adalah dua bidang lateral paralel dan berlawanan serta bidang anterior supraklavikula. ${ }^{13,14}$ Batas bidang lateral (tumor primer dan leher atas) pada superior : dasar tengkorak, inferior : seluruh leher dengan menarik bahu sejauh mungkin, posterior : prosesus spinosus vertebraedan anterior : $2-3 \mathrm{~cm}$ tepi tumor. ${ }^{13}$

Dosis radioterapi :

Bidang berlawanan - paralel sampai 46 Gy dengan 2 Gy/hari. ${ }^{43}$ Radiasi ini menggunakan sinar $\mathrm{X}$ atau Co-60 $6 \mathrm{MeV}$, kemudian ditambah 4 Gy tanpa mengenai tulang belakang. Setelah 50 Gy (tumor primer ditambah $2 \mathrm{~cm}$ tepi tumor), dosis radioterapi ditambah sehingga menjadi total $66-72$ Gy. ${ }^{4,13,17}$

Jika tidak ada keterlibatan KGB, dosis elektif leher adalah 50 Gy. ${ }^{13,16}$ 
Jika terdapat pembesaran KGB kurang $3 \mathrm{~cm}$, dosis radioterapi adalah 60 Gy tetapi jika pembesaran KGB lebih $6 \mathrm{~cm}$ adalah $66-72$ Gy. $^{13}$

\section{Tumor Ganas Hipofaring}

Bidang radioterapi hipofaring adalah dua bidang lateral paralel - berlawanan dan bidang anterior supraklavikula. ${ }^{13,14}$ Batas bidang lateral (tumor primer dan leher atas); superior : mastoid dan dasar tengkorak, meliputi KGB retrofaring, inferior : seluruh leher, dengan menarik bahu sejauh mungkin (minimal $1 \mathrm{~cm}$ dibawah tumor), posterior: prosesus spinosus vertebrae dan anterior : $2-3 \mathrm{~cm}$ anterior tumor ${ }^{13,18}$

Dosis radioterapi :

Bidang palalel berlawanan sampai 46 Gy dengan 2 Gy/hari. ${ }^{4,13}$ Radiasi ini menggunakan sinar $X$ atau Co-60 $6 \mathrm{MeV}$, kemudian 4 Gy tanpa mengenai tulang belakang. ${ }^{13}$ Setelah $50 \mathrm{~Gy}$, dosis radioterapi ditingkatkan menjadi totalnya 66 - 72 Gy. ${ }^{4,13}$

Jika tidak ada keterlibatan KGB, dosis elektif leher adalah $50 \mathrm{~Gy} .{ }^{13,16}$ Jika terdapat pembesaran KGB kurang $3 \mathrm{~cm}$, dosis radioterapi adalah 60 Gy. tetapi jika pembesaran KGB lebih $6 \mathrm{~cm}$ adalah 66 - 72 Gy. ${ }^{13}$ Total dosis radioterapi pasca operasi adalah 60 Gy, tetapi jika batas tumor positif maka total dosis menjadi 66 Gy. ${ }^{13,16}$

\section{Tumor Ganas Supraglotis}

Radioterapi ini menggunakan sinar $\mathrm{X}$ atau Co-60 6 MeV. ${ }^{17}$ Batas radioterapi tumor ganas glotis T3 - 4 dan supraglotis; superior : superior angulus mandibular, inferior : dasar kartilago krikoid, anterior : $0,5-1 \mathrm{~cm}$ dari kulit dan sepertiga mandibular, posterior : prosesus spinosus. ${ }^{13}$ Apabila terdapat perluasan ke subglotis, dilakukan penarikan bahu sejauh mungkin Jika pasien menjalani operasi, radiasi dilakukan 1,5 cm diatas stoma (stoma diterapi dengan bidang supraklavikula). ${ }^{13,18}$

\section{Tumor Ganas Glotis}

Radioterapi ini menggunakan sinar $\mathrm{X}$ atau Co-60 $6 \mathrm{MeV} .^{17}$ Batas radioterapi tumor ganas glotis T1-2; superior : puncak kartilago tiroid Inferior : dasar kartilago krikoid, anterior : 0,5 - $1 \mathrm{~cm}$ dari kulit dan posterior : bagian depan korpus vertebrae. ${ }^{13,18}$

\section{Tumor Ganas Subglotis}

Radioterapi ini menggunakan sinar $\mathrm{X}$ atau Co-60 6 MeV. $^{17}$ Batas radioterapi tumor ganas subglotis; superior : level II (KGB jugularis atas), inferior : $2 \mathrm{~cm}$ di bawah tumor primer, anterior dan posterior : sama dengan bidang supraglotis

Jika terdapat keterlibatan KGB leher bawah dan mediastinum superior, KGB ini diterapi sesuai dengan bidang supraklavikula anterior. ${ }^{13}$

\section{Tumor Ganas Rongga Mulut}

Bidang konvensional radioterapi tumor ganas rongga mulut menggunakan dua bidang lateral paralel - berlawanan dengan batas superior : $2 \mathrm{~cm}$ di atas tumor, inferior : di bawah tulang hyoid, anterior : 2 $\mathrm{cm}$ di depan tumor primer dan posterior : bagian belakang korpus vertebrae.

Radioterapi pada tumor ganas dasar mulut, lidah, bibir dan mukosa bukal dapat menggunakan brakiterapi saja atau dengan kombinasi dengan radioterapi eksterna yaitu dengan menggunakan dua bidang lateral dan satu bidang anterior. ${ }^{13}$ Radioterapi ini menggunakan sinar X $4 \mathrm{MeV}$. Dosis yang diberikan pada tumor ganas rongga mulut adalah 5 fraksi perminggu sampai tercapai total 15 atau 16 fraksi dengan dosis $52-55$ Gy. ${ }^{17}$

\section{Tumor Ganas Sinonasal}

Radioterapi tumor ganas sinonasal umumnya menggunakan satu bidang anterior dan satu bidang ipsilateral. Batas bidang radioterapi tumor ganas sinonasal; superior : $1 \mathrm{~cm}$ di atas sinus ethmoid inferior : sudut bibir, anterior : kantus lateral orbita dan posterior : meliputi KGB retrofaring ${ }^{13}$

Dosis radiasi:

Dosis perfraksi adalah 1,8 - 2 Gy. ${ }^{13}$ Total dosis definitif radioterapi/kemoradioterapi adalah 66 - 70 Gy, sedangkan total dosis radioterapi pasca operasi adalah 60 Gy dan 66 Gy jika batas tumor positif. ${ }^{13,16}$

\section{Energi radiasi}

Menggunakan sinar $\times \quad 4-6$ megavolt. $^{17}$ Penggunanaan Co-60 tidak direkomendasikan pada tumor ganas sinonasal. ${ }^{13}$

\section{Pengaruh Radioterapi Tumor Ganas Kepala Leher terhadap Kelenjar Tiroid}

Radioterapi pada tumor ganas kepala dan leher dapat meyebabkan kelainan pada kelenjar tiroid berupa hipotiroid, tiroiditis dan nodul tiroid. ${ }^{5}$ Hipotiroid merupakan efek samping yang paling sering ditemukan pasca radioterapi kepala dan leher yaitu sekitar 19 - $53 \%{ }^{6}{ }^{6}$ Mekanisme terjadinya hipotiroid pasca radioterapi tumor ganas kepala dan leher masih kontroversi. $^{19}$ Hipotiroid ini dihubungkan dengan kerusakan sel dan pembuluh darah kecil kelenjar tiroid serta fibrosis kapsul kelenjar tiroid. ${ }^{5,20}$ Kerusakan pembuluh darah kecil ini akan menyebabkan terjadinya proliferasi endotelial, degenerasi sel yang selanjutnya akan menyebabkan terjadinya nekrosis dan fibrosis. Menurut Fonkalsrud et al yang dikutip Tetik $^{21}$ pada pengamatan pembuluh darah pasca radioterapi menggunakan mikroskop elektron terlihat fibrosis pada dinding pembuluh darah sehingga menyebabkan penyempitan lumen. Penyempitan lumen akan menyebabkan terjadinya hipoksemia dan sel kelenjar tiroid akan kekurangan nutrisi sehingga mengurangi kemampuan sintesis dan sekresi kelenjar tiroid. Keadaan ini akan diperberat dengan adanya fibrosis kapsul kelenjar tiroid sehingga akan menghambat kompensasi hipertrofi kelenjar tiroid. ${ }^{19}$ 
Menurut Lo Galbo dikutip Miller ${ }^{19}$ dosis lebih dari 2,25 Gy akan menginduksi kematian sel folikuler kelenjar tiroid melalui mekanisme apoptosis.

Terdapat hipotesis lain bahwa hipotiroid pasca radioterapi dapat terjadi akibat dimediasi imun. $^{21}$ Teori ini awalnya dipresentasikan Markson et al dimana kerusakan inti sel tiroid akan menginduksi respon imun terhadap jaringan normal. ${ }^{19}$ Menurut Lin $\mathrm{Z}^{22}$ setelah radiasi dosis tinggi kelenjar tiroid akan mengalami inflamasi dan akan menjadi pemicu produksi anti TPO. Anti TPO akan menghancurkan enzim TPO sehingga akan menghalangi produksi hormon tiroid yang selanjutnya akan menyebabkan terjadinya hipotiroid. ${ }^{22}$

Faktor risiko untuk terjadinya hipotiroid antara lain usia muda, perempuan dan terdapat tindakan pembedahan pada leher. $^{20,22-26}$ Risiko hipotiroid meningkat dengan peningkatan volume radiasi atau radiasi leher bilateral. ${ }^{20}$

Kelenjar tiroid yang terpapar dalam target volume radioterapi baik seluruh maupun sebagian tergantung dari lokasi tumor primer dan metastasis servikal. ${ }^{27}$ Hipotiroid umumnya terjadi dalam 2 tahun pertama pasca radioterapi tumor ganas kepala dan leher. Peningkatan dosis yang mengenai kelenjar tiroid akan memperpendek masa laten. ${ }^{28}$ Menurut Miller ${ }^{19}$ kejadian paling awal hipotiroid dapat diamati pada 4 - 6 minggu setelah pengobatan lengkap. Srikantia et $\mathrm{al}^{30}$ melaporkan kejadian hipotiroid subklinis sebesar $11,1 \%$ pada 9 bulan pasca radioterapi. Survei Wickham yang dikutip Srikantia ${ }^{30}$ memperlihatkan risiko terjadinya hipotiroid klinis sebesar 38 kali. Menurut Bhandare dikutip Akgun ${ }^{31}$ radioterapi yang lebih dari 45 Gy akan menyebabkan terjadinya hipotiroid. Insiden hipotiroid akibat radioterapi dapat dikurangi dengan mengurangi volume radiasi kelenjar tiroid atau mengurangi lapangan radioterapi. ${ }^{32}$ Menurut Fujiwara ${ }^{33}$, kelenjar tiroid yang rata-rata menerima dosis kecil dari $30 \mathrm{~Gy}$ memiliki kemungkinan untuk terjadinya hipotiroid lebih kecil dibanding dengan kelenjar tiroid yang menerima dosis lebih dari 30 Gy.

Hipotiroid akibat radiasi ini bersifat irreversibel dan mempegaruhi kualitas hidup pasien. ${ }^{6,20,34,35}$ Hipotiroid akibat radiasi ini ditatalaksana dengan penggantian hormon tiroid menggunakan levothyroxine, dimulai dari dosis $1,6 \mu \mathrm{g} / \mathrm{kg} / \mathrm{hari}$ dan dosis diturunkan mengikuti gejala dan kadar TSH dipertahankan dalam rentang batas bawah referensi. ${ }^{19,36}$ Kadar $\mathrm{TSH}$ dan $\mathrm{T}_{4}$ diperiksa setiap 8 sampai 12 minggu sampai dosis stabil tercapai. ${ }^{27}$ National Comprehensive Cancer Network (NCCN) merekomendasikan pemeriksaan fungsi tiroid setiap 6 sampai 12 bulan setelah radioterapi di leher. ${ }^{19,20,28}$ Dengan pengenalan dan penanganan hipotiroid secara dini akan memperbaiki kualitas hidup sehingga pasien akan merasakan kenyamanan fisik dan psikis. ${ }^{26}$

\section{Kesimpulan}

Radioterapi tumor ganas kepala dan leher sering menimbulkan efek samping pada kelenjar tiroid berupa hipotiroid. Hipotiroid ini dapat dideteksi dengan pemeriksaan fungsi tiroid yaitu $\mathrm{TSH}$ dan $\mathrm{T}_{4}$. Hipotiroid pasca radioterapi ini bersifat irreversibel dan mempengaruhi kualitas hidup pasien. Oleh karena itu NCCN merekomendasikan pemeriksaan berkala fungsi tiroid pasca radioterapi tumor ganas kepala dan leher.

\section{Daftar Pustaka}

1. Cognetti DM, Weber RS, Lai SY. Head and neck cancer: an evolving treatment paradigm. Cancer 2008; 113 (70): 1911-32

2. Pannone G, Santoro A, Papagerakis S, Muzio L, Rosa $G$, Bufo $P$. The role of human papillomavirus in the pathogenesis of head \& neck squamous cell carcinoma: an overview. Infect Agent Cancer 2011; 6(4): 1-11

3. Maruyama $\mathrm{H}$, Yasui $\mathrm{T}$, Fujiwara TI, Morii E, Yamamoto $\mathrm{Y}$, Yoshii $\mathrm{T}$ et al. Human papillomavirus and p53 mutations in head and neck squamous cell carcinoma among Japanese population. Cancer Sci 2014; 105 (4): 409-17

4. Nuyts S. Radiotherapy and chemoradiotherapy of the head and neck. In: Hermans R, Reznek RH, Husband JE, editors. Squamous cell cancer of the neck. $1^{\text {st }}$ ed. New York: Cambridge university press; 2008: p. 19-34

5. Lin Z, Wu C, Lin J, Feng H, Chen L. A longitudinal study on the radiation-induced thyroid gland change after external beam radiotherapy on nasopharyngeal carcinoma. Mary Ann Liebert 2011; 21(1): 19-24

6. Boomsma MJ, Bijl HP, Christianen ME, Beetz I, Chouvalova O, Steenbakkers RJ et al. A prospective cohort study on radiation-induced hypothyroidism: development of an NCTP model. Int J Radiation Oncol Biol Phys 2012; 84(3): 351-6

7. Statathos N. Anatomy and physiology of the thyroid gland clinical correlates to thyroid cancer. In: Wartofsky L, Nostrand DV, editors. Thyroid cancer a comprehensive guide to clinical management. $2^{\text {nd }}$ ed. New Jersey: Humana press; 2006: p. 3-5

8. Stewart WB, Rizzolo LJ. Embryology and surgical anatomy of the thyroid and parathyroid gland. In: Oertli D, Udelsman R, editors. Surgery of the thyroid and para thyroid gland. $1^{\text {st }}$.New York: Springer Berlin Heidelberg; 2007: p. 13-20

9. Brams EO. Thyroid testing and imaging. In: Skolnik NS, editor. Thyroid disease a case based and practical guide for primary care. $1^{\text {st }}$ ed. New Jersey: Humana press; 2005: p. 9-19

10. Zhang I, Jablonski SD, Ferris RL. Treatment of thyroid neoplasma. In: Johnson JT, Rosen CA, Newland S, Amin M, Branstetter B, Casselbrant $\mathrm{M}$, et al, editors. Baileys head and neck surgery otolaryngology. $5^{\text {th }}$ ed. Philadelphia: Lippincott Williams \& Wilkins; 2014: p. 2115-30 
11. Pellitteri PK, Ing S, Jameson B. Disorder of the thyroid. In: Flint PW, Haughey $\mathrm{BH}$, Lund VJ, Niparko JK, Ricardson MA, Robbins KT et al, editors. Cummings otolaryngologyhead and neck surgery. $5^{\text {th }}$ ed. Philadelphia: Mosby elsevier; 2010: p. 1736-49

12. Braverman LE, Utiger RD. Introduction to hypothyroidism. In: Braverman LE, Utiger RD, editors. Werner \& ingbars the thyroid: a fundamental and clinical text. $9^{\text {th }}$ ed. Boston: Lippincot Willian \& Wilkins; 2005: p. 698-9

13. Ozyigit G, Beyzadeoglu M, Ebruli C. Head and nek cancer. In: Ozyigit G, Beyzadeoglu M, Ebruli $\mathrm{C}$, editors. Basic radiation oncology. $1^{\text {st }} \mathrm{ed}$. Berlin: Springer-verlag berlin Heidelberg; 2010: p. 205301

14. Hong TS, Tome WA, Harari PM. Therapy in the management of the head and neck cancer. In: Adelstein DJ, editor. Squamos cell head and neck cancer recent clinical progress and prospects for the future. $1^{\text {st }}$ ed. New Jersey: Humana press; 2005: p.115-24

15. Lee AW, Yeung RM, Ng WT. Nasopharynx. In: Harari PM, Connor NP, Grau C. Functional preservation and quality of life in head and neck cancer radiotherapy. $1^{\text {st }}$ ed. Berlin: springerverlagheidelberg; 2009: p. 57-73

16. Russo G, Machtay M. Intensity-modulated radiation therapy: promised and practice. In: Posner MR, editor. Options in the treatment of head and neck cancer. $1^{\text {st }}$ ed. Massachusetts: CMP medica; 2006: p. 91-113

17. Duthie MB, Gupta NK, Pointon RC. Head and neck. In: Pointon RC, editor. The radiotherapy of malignant disease. $2^{\text {nd }}$ ed. London: Springerverlag; 1991: p. 145-205

18. Hinerman RW, Mendelhall WM, Amdur RJ. Radiation therapy in the management of earlystage head and neck cancer. In: Brockstein $B$, Masters G, editors. Head and neck cancer. $1^{\text {st }}$ ed. New York: Kluwer academic; 2003: p. 115-44

19. Miller MC, Agrawal A. Hypothyroidism in postradiation head and neck cancer patients: incidence, complications, and management. Curr Opin Otolaryngol Head Neck Surg 2009; 17: 111 5

20. Kim MY, Yu T, Wu HG. Dose-volumetric parameters for predicting hypothyroidism after radiotherapy fo head and nead and cancer. Jpn J Clin Oncol 2014; 44: 331-7

21. Tetik O, Yetkin U, Calli AO, Ilhan G, Gurbuz A.Occlusive arterial disease after radiotherapy for testicular cancer: case report and review of the literature. Vascular 2008; 16(4): 239-241.

22. Lin Z, Chen L, Fang Y, Cai A, Zhang T, Wu VW. Longitudinal study on the correlations of the thyroid antibody and thyroid hormone levels after radiotherapy in patients with nasopharyngeal carcinoma with radiation-induced hypothyroidism. Head and Neck 2014; 36(2): 171-5.
23. Chyan A, Shugard E, lambert L, Quivey JM, Yom SS. Dosimetric predictors of hypothyroidism in oropharyngeal cancer patient treated with intensity-modulated radiation therapy. Radiat Oncol, 2014; 9(1): 1-7

24. Vogelius IR, Bentzen SM, Maraldo MV, Petersen PM, Specht L. Risk factor for radiation-induced hypothyroidism: a literature-based meta-analysis. Cancer 2011; 117(23): 5250-60.

25. Sachdev S, Refaat T, Bacchus ID, Sathiaseelan $\mathrm{V}$, Mittal BB. Thyroid V50 highly predictive of hypothyroidism in head-and-neck cancer patients treated with intensity-modulated radiotherapy. Am J Clin Oncol 2014; 1 -5

26. Alterio D, Jereczek BA, Franchi B, D'Onofrio A, Piazzi V, Rondi E. Thyroid disorder in patient treated with radiotherapy for head-and-neck cancer: a retrospective analysis of seventy-three patients. Int J Radiation Oncol Biol Phys 2007; 67(1): 144-50.

27. Bonato CC, Dias HB, Alves M, Duarte LO, Dias $\mathrm{TM}$, Dalenogare $\mathrm{MO}$ et al. In vivo dosimetry of thyroid doses from different irradiated sites in children and adolescents: a cross sectional study. Radiat Oncol 2014; 9(40): 1-8.

28. Bernat L, Hrusak D. Hypothyroidism after radiotherapy of head and neck cancer. J Craniomaxillofac Surg 2014; 42: 356-61.

29. Lin Z, Wang X, Xie W, Yang Z, Che K, Wu WC. Evaluation of clinical hypothyroidism risk due to irradiation of thyroid and pituitary gland in radiotherapy of nasopharyngeal cancer patient. J Med Imaging Radiat Oncol 2013; 57: 713-8.

30. Srikantia N, Rishi KS, Janaki MG, Bilimagga RS, Ponni A, Rajeev AG et al. How common is hypothyroidism after external radiotherapy to neck in head and neck cancer patient?. Indian J Med Paediatr Oncol 2011; 32(3): 143-8.

31. Akgun Z, Atasoy BM, Ozen Z, Gulluoglu B, Sengoz M. V30 as a predictor for radiationinduced hypothyroidism: a dosimetric analysis in patients who received radiotherapy to the neck. Radiat Oncol 2014; 9(1): 1-5.

32. Diaz R, Jaboin JJ, Paliza MM, Koehler E, Phillips $J G$, Stinson $S$ et al. Hypothyroidism as a consequence of intensity-modulated radiotherapy with concurrent taxane-based chemotherapy for locally advanced head-and-neck cancer. Int J Radiation Oncol Biol Phys 2010; 77(2): 468-76.

33. Fujiwara M, Kamikonya $N$, Odara S, Sizuki $H$, Niwa $Y$, Takada $Y$ et al. The threshold of hypothyroidism after radiation therapy for head and neck cancer: a retrospective analysis of 116 patients. J Radiat Res 2015; 56(3): 557-82.

34. Bolling T, Geisenheiser A, Pape H, Martini C, Rube C, Timmermann B et al. Hypothyrodism after head-and-neck radiotherapy in children and adolescents: preliminary result of the"register for the evaluation of side effect after radiotherapy in 
childhood and adolescents" (RiSK). Int J Radiation Oncol Biol Phys 2011; 81(5): 787-91.

35. Ronjom MF, Brink C, Bentzen SM, Hegedus L, Overgaard J, Johansen J. Hypothyroidism after primary radiotherapy for head and neck squamous cell carcinoma: normal tissue complication probability modeling with latent time correction. Radiother Oncol 2013; 109: 317-22.

36. Garber JR, Cobin RH, Gharib H, Hennesey JV, Klein I, Mechanick $\mathrm{Jl}$ et al. Clinical practice guideline for hypothyroidism in adults: cosponsored by the american association of clinical endocrinologist and the american thyroid association. Endocr Pract 2012; 18(6): 1-45 